\section{'Mountain Regina': Multiple Disease Resistant Fresh-market Hybrid Tomato and Its Parents, NC 1LF and NC 2LF}

\author{
Dilip R. Panthee \\ Department of Horticultural Science, North Carolina State University, \\ Mountain Horticultural Crops Research and Extension Center, 455 \\ Research Drive, Mills River, NC 28759-3423
}

Additional index words. crimson, large-fruited tomato, $I-3$ gene, ogc gene, Mi gene, $S w-5$ gene, $T m-2$ gene

'Mountain Regina' is a large-fruited, freshmarket hybrid tomato (Solanum lycopersicum L.) adapted to vine-ripe production. It is resistant to verticillium wilt (Verticillium dahliae $\mathrm{Kleb)}$ race 1 (Ve gene); fusarium wilt [Fusarium oxysporum f.sp. lycopersici (Sacc.) Snyd. and Hans.] races 1,2 , and $3(I, I-2$, and $I-3$ genes); root-knot nematodes (Meloidogyne spp., $\mathrm{Mi}$ gene); Tomato mosaic virus (Tm-2 gene); and Tomato spotted wilt virus ( $\mathrm{Sw}-5$ gene).

\section{Origin}

The 'Mountain Regina' $F_{1}$ hybrid resulted from the cross of NC 1LF $\times$ NC $2 \mathrm{LF}$ (Fig. 1). Both parents are inbred lines developed as part of the North Carolina State University (NCSU) tomato breeding program, released through the NCSU breeders release board, and disclosed through the NCSU Office of Technology Transfer.

NC 1 LF resulted from selfing NC 056, the $\mathrm{F}_{1}$ hybrid of NC123S $\times 0255(\mathrm{x})-1-1$ (Fig. 1) . NC $123 \mathrm{~S}$ is a large-fruited tomato breeding line with desirable horticultural traits and multiple disease resistance genes ( $V e, I, I-2$, $I-3, S w-5$, and $M i$ genes) obtained from selfing the 'Amelia' $F_{1}$ hybrid (Gardner and Panthee, 2012). NC 1LF is derived from the same cross (NC 056) leading to NC 1CS, the parent of 'Mountain Majesty' (Panthee and Gardner, 2011), and diverging from NC 1CS in the $\mathrm{F}_{3}$ generation. The objective of breeding NC 1 LF was to incorporate desirable fruit characteristics and superior combining ability from NC 84173 (Gardner, 1992) together with the crimson gene $\left(o g^{c}\right)$ for increased red fruit color and lycopene content plus additional disease resistance genes. The

Received for publication 7 Mar. 2021. Accepted for publication 2 Apr. 2021.

Published online 19 May 2021.

The tomato breeding program at North Carolina State University was supported by the North Carolina Tomato Growers Association and the Hatch project of the U.S. Department of Agriculture.

D.R.P. is the corresponding author. E-mail: Dilip_panthee@ncsu.edu.

This is an open access article distributed under the CC BY-NC-ND license (https://creativecommons. org/licenses/by-nc-nd/4.0/). were made from a large $F_{2}$ population at Mountain Horticultural Crops Research \& Extension Center (MHCREC), Mills River, NC, for disease resistances, large fruit size, yield, and other desirable horticultural traits in the $\mathrm{F}_{2}$ through $\mathrm{F}_{5}$ generations derived from selfing $\mathrm{NC} 1086$. Seeds of the $F_{6}$ generation were bulked to produce the $\mathrm{F}_{7}$-generation inbred line released as NC 2LF (Fig. 1).

The combination of a high level of resistance to Tomato spotted wilt virus, Tomato mosaic virus, and root knot nematodes; resistance to verticillium wilt and races 1,2 , and 3 of fusarium wilt; a high marketable yield of large fruit desired for vine-ripe production; and improved red color and lycopene content make 'Mountain Regina' a unique hybrid. More important, this hybrid matures about a week earlier than the standard control, 'Mountain Majesty', which is a benefit for tomato growers seeking earlier maturity (Table 1). Results from multiple replicated trials indicated that the performance of 'Mountain Regina' is highly stable in North Carolina and equivalent in yield to other widely grown hybrids (Fig. 1).

\section{Description}

When averaged over four replicated trials conducted at the MHCREC in Summer 2014-17, 'Mountain Regina' was not statistically different from 'Mountain Fresh' (Gardner, 1999), 'Mountain Majesty' (Panthee and Gardner, 2011), and 'Red Defender' in total yield, marketable yield, market able percentage, and fruit size (Table 1). The total and marketable yields of 'Mountain Regina' were significantly greater than 'Mountain Majesty' in 2014 when there was severe Tomato spotted wilt virus infection in the field. It should be noted that both the hybrids were resistant to Tomato spotted wilt virus. A high percentage of the fruit of 'Mountain Regina' was in the jumbo size category (diameter, $>3.5$ inches), which is highly desirable for vine-ripe tomatoes and for which growers are often paid a premium over smaller fruit sizes.

Fruit of 'Mountain Regina' develop a deep-red color, which results from the 


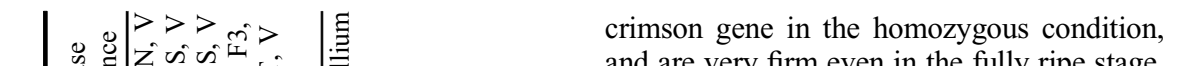
$\begin{array}{ll} & \text { and are very firm even in the fully ripe stage. } \\ 0 & \text { Immature fruit have a glossy, uniform green }\end{array}$

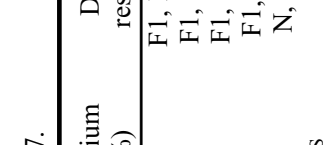
Fruit shape is deep oblate to the flattened globe, with smooth blossom end scars, and have excellent resistance to fruit cracking and weather check. When six tomato varieties were evaluated for overall taste and flavor, 'Mountain Regina' was rated one of the best in a subjective taste evaluation in research station plots (Fig. 2). These varieties had a different genetic background, and the best-rated variety (NC 14078) is resistant to fusarium wilt (races 1 and 2; $I$ and $I-2$ genes), Tomato mosaic virus (Tm2 gene), Tomato spotted wilt virus ( $\mathrm{Sw}-5$ gene), and verticillium wilt ( $V e$ gene).

The plant growth habit of NC 1LF is vigorous and determinate ( $s p$ gene), with attractive, heavy foliage cover. Fruit are very large, smooth, and deep oblate in shape (similar to NC 84173), and have jointed pedicels. Immature fruit are uniformly light green ( $u$ gene). exterior and interior color as a result of the crimson gene. Disease resistances include verticillium wilt ( $\mathrm{Ve}$ gene), fusarium wilt races 1,2 , and 3 (I, I-2, and $I-3$ genes), rootknot nematodes (Mi gene), and Tomato spotted wilt virus ( $S w-5$ gene).

NC 1LF is susceptible to weather check, which is one of the main reasons for reducing its marketable yield. The fruit are deep oblate in shape, and thus are worth making crosses with a Ripe fruit are firm and develop a bright-red round or deep, round fruited lines that combine well for improved fruit size in $F_{1}$ hybrids. Several NCSU-released hybrids and seed company hybrids make use of a large round tomato as one of the parent lines in hybrids.

The plant habit of NC 2LF is vigorous and determinate, with attractive, heavy foliage cover. Fruit are very large, smooth, slightly flat in shape, and have jointed pedicels. Immature fruit are uniformly light green ( $u$ gene). Ripe fruit are firm and develop a bright-red exterior and interior color as a result of the crimson gene. Disease resistances include verticillium wilt ( $\mathrm{Ve}$ gene), fusarium wilt races 1 and 2 ( $I$ and $I-2$ genes), and $T o$ mato mosaic virus ( $\mathrm{Tm}-2$ gene). The average fruit weight was $286 \mathrm{~g}$ (range, 241-309 g) in the replicated trials.

\section{Uses}

'Mountain Regina' adds to earlier hybrids released from the NCSU tomato breeding program by incorporating earlier maturity and increased disease resistance genes beyond those present in previous hybrids. $\mathrm{NC}$ 1LF and NC 2LF will be useful in breeding or as parents in additional hybrids because of the combinations of disease resistance genes and fruit-quality traits along with the ogc gene. 'Mountain Regina' is a vigorous, determinate plant ( $s p$ gene) similar in height to that of 'Mountain Fresh' and 'Mountain Majesty' when staked. Foliage provides adequate cover for fruit protection.

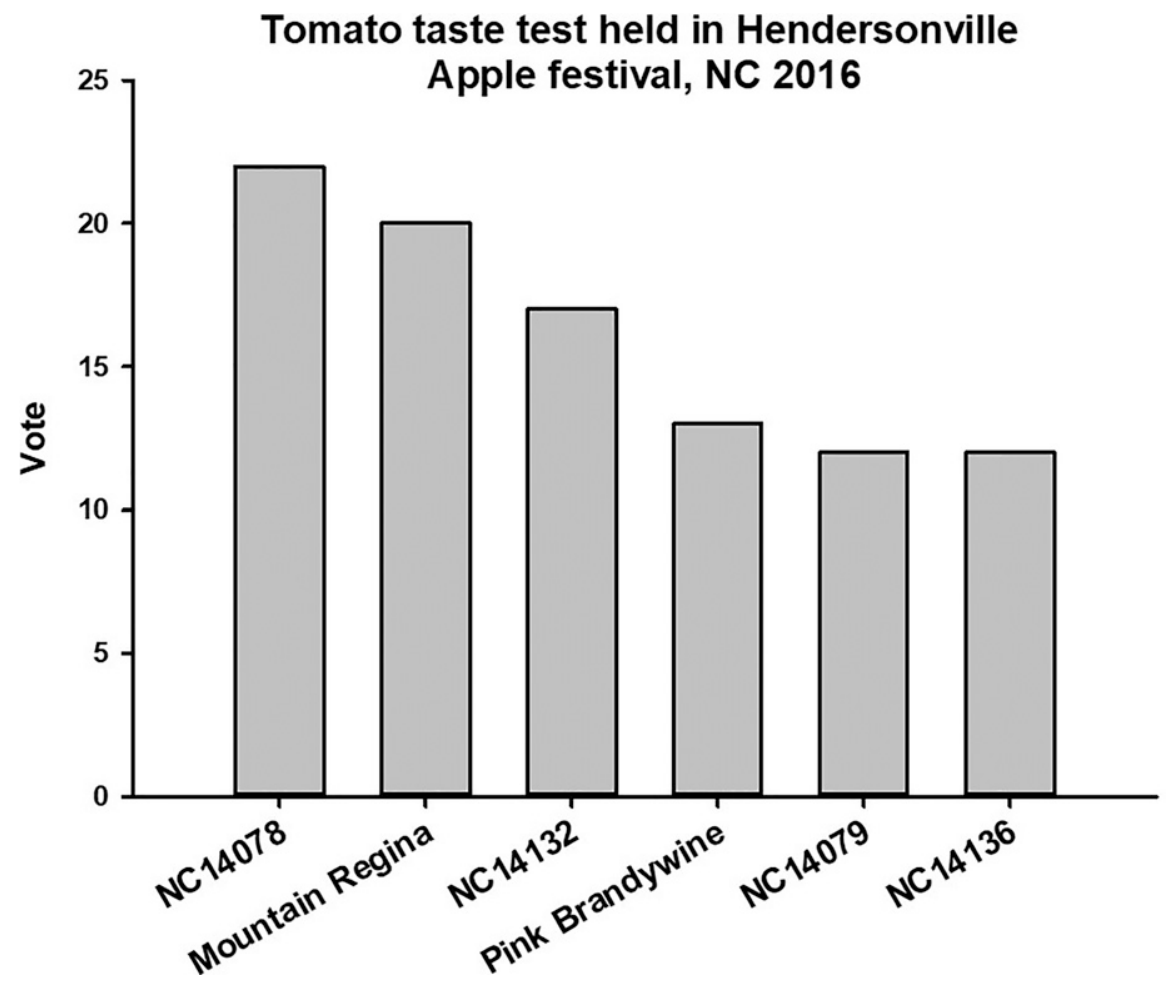

Fig. 2. A tomato taste test was held in Hendersonville during the apple festival. A blind taste test was conducted by an untrained panel. The taste was conducted by County Extension agent. The panelists were asked to rank the best variety (out of six) based on their overall taste preference. The figure presents the overall ranking based on voting by the taste panelists. 


\section{Availability}

We plan to license 'Mountain Regina' to a private seed company on an exclusive basis for seed production and sales. It is expected that commercial seed will be available in 2022. Distribution of seed of NC 1LF and NC 2LF to other breeders requires a signed material transfer agreement, which can be downloaded from http://www.mountainhort.ncsu.edu/programs /tomato/releases/tomato-seed-transfer-agreem ent.pdf. Small trial samples of 'Mountain Regina' are available from D.R.P. (dilip_panthee @.ncsu.edu), MHCREC, 455 Research Drive, Mills River, NC 28759.

\section{Literature Cited}

Gardner, R.G. 1992. Mountain Spring tomato: NC8276 and NC-84173 tomato breeding lines. HortScience 27:1233-1234.
Gardner, R.G. 1999. NC 109 tomato breeding line: 'Mountain Fresh' F-1 hybrid. HortScience 34:941-942.

Gardner, R.G. and D.R. Panthee. 2012. Tomato spotted wilt virus-resistant fresh-market tomato breeding lines: NC 58S, NC $123 \mathrm{~S}$, NC $127 \mathrm{~S}$, and NC 132S. HortScience 47:531-532.

Panthee, D.R. and R.G. Gardner. 2011. 'Mountain Majesty': A tomato spotted wilt virus-resistant fresh-market hybrid tomato and its parents NC 714 and NC 1CS. HortScience 46:1321-1323, doi: 10.21273/HORTSCI.46.9.1321. 